\title{
DEMOCRACY AND LEGISLATIVE PROCEEDINGS IN SPAIN
}

Summary: 1. Introduction; 2. The constitutional amendment procedure; 3. Legislative proceedings and Finance Bills; 4. Other Parliament's Decisions with the weight of parliamentary legislation; 5. Democracy, rule of law and protection of Parliament's minorities.

Keywords: democracy, constitutional amendment procedure, legislative proceedings, Decisions with the weight of parliamentary legislation, parliament's minorities.

Abstract: This paper reviews certain decisions adopted recently by the Spanish Constitutional Court (STC 136/2011, ATC 7/2012 and ATC 9/2012), which reveal a certain disregard for rule of law in legislative proceedings. This affects Parliament's minorities insofar as it prevents or hinders their legislative participation and their access to the Constitutional Court, both key elements in any democratic state.

\section{Introduction}

The recent disregard for procedures in Spain is viewed with concern. Time constraints have been used as an argument to explain and justify why greater importance should often be attributed to substance rather than form, ignoring the fact that both elements are so intimately related that sacrificing form inevitably affects substance as well. What is truly worrying is that such behaviour may not only undermine the legal system but also erode key principles in a democratic rule of law when certain provisions guaranteeing those principles are ignored. Good examples of such practices include the hurried constitutional reform of August 2011 or proposals to reduce the deadlines for the transfer of power and expedite the investiture of the President of the Government without taking into account the resolution of electoral petitions and also proposals on the formation of parliamentary groups with members "lent" by other political parties.

Outside the political arena in which this type of behaviour has been observed, its parallel can also be found in the judicial sphere, which is even more disheartening. Constitutional Court Judgment No. STC 136/2011 (Official State Gazette (BOE) of October 11, 2011) seems to reveal certain contempt for the legislative process on the 
part of the Constitutional Court, which put a stamp of constitutionality on the individual laws accompanying the Budget Law. The discourse changed recently, and not necessarily for the better in guarantee terms, in Constitutional Court Decision No. 9/2012 (Official State Gazette (BOE) of February 11, 2012), in which the Court rejected the appeal for the protection of constitutional rights lodged against various acts of Congress on the grounds that they infringed Section 23.2 of the Spanish Constitution during the passing of the latest constitutional reform described above, including those acts that kept it within the purview of Section 167 of the Spanish Constitution, those that allowed this process to follow emergency and single reading procedures or those that rejected the amendment of the complete text and its replacement with an alternative text. Another Order, No. 7/2012 published on the same date, which dismissed the appeal for protection filed by air traffic controllers against the Agreement adopted by the Spanish Parliament authorising the extension of the state of emergency declared in response to their wildcat strike, also calls into question respect for formal procedures by questionably giving this authorisation force-of-law status and its subsequent effects on the control to which this authorisation must be subjected and on those responsible for promoting it.

These are not the only cases that can be highlighted but they are the most recent examples. Since they concern such different spheres, they may evidence the trend described in this study. This is a difficult time for substance and procedures, and the victims are democratic principle and minorities. This study examines the aforementioned trend in the cases described herein and following the most logical chronological order.

\section{The constitutional amendment procedure}

The process to reform Section 135 of the Spanish Constitution began on August $26,2011^{1}$, the aim being to demonstrate Spain's unequivocal commitment to achieving budgetary stability and reducing the public deficit by including limits in the Spanish Constitution that could build confidence and reassure the European Union, other States

\footnotetext{
${ }^{1}$ The original version of Section 135 of the Spanish Constitution established the following:

"1. The Government must be authorised by law in order to issue Public Debt bonds or to contract loans.

2. Loans to meet payment on the interest and capital of the State Public Debt shall always be understood to be included in budget expenditure and may not be subject to amendment or modification as long as they conform to the terms of the law of issue".
} 
and markets ${ }^{2}$.

Socialist and PP members presented a joint proposal to the Lower House of Parliament to amend the abovementioned constitutional provision, which, after being admitted for processing and publication, was submitted for consideration by the plenary session of the Lower House and for it to rule on the passing of the amendment through the single reading procedure, which took place on August 30. On the same day, the Bureau decided that if Parliament approved the aforementioned amendments, as it eventually did, the initiative would be processed by means of the emergency procedure requested by the proponents and a period would be established for tabling amendments ending on September 1. Since the Bureau did not change its decision, despite a request

\footnotetext{
${ }^{2}$ The new text of Section 135 of the Spanish Constitution states that:

"1. All Public Administrations shall adapt their actions to the principle of budgetary stability.
}

2. The State and the Autonomous Communities shall not incur any structural deficit exceeding the margins set, if any, by the European Union on its Member States. An organic law will establish the maximum structural deficit allowed for the State and for the Autonomous Communities, according to their gross domestic product. The Local Authorities shall establish a budgetary stability.

3. The State and the Autonomous Communities must be authorized by law in order to issue Public Debt bonds or to contract loans. Loans to meet payment on the interest and capital of the Administrations' Public Debt shall always be deemed to be included in their budgetary expenditure and their payment will be an absolute priority. These loans may not be subject to amendment or modification as long as they conform to the terms of issue. The amount of Public Debt of all the Public Administrations with regard to the State's gross domestic product shall not exceed the benchmark set forth in the Treaty on the Functioning of the European Union.

4. The thresholds of the structural deficit and the amount of Public Debt shall only be exceeded in case of acts of God, economic recession or situations of extraordinary emergency beyond the State's control and that significantly affect the State's financial situation or economic or social sustainability, deemed by the absolute majority of the members of the Congress.

5. An organic law will develop the principles referred to in this Section, as well as the participation, in the appropriate proceedings, of the institutional coordination bodies between the Public Administrations on fiscal and financial policies. At any rate, it will regulate:

a) The distribution of the deficit and debt thresholds between the Public Administrations, the hypothetical exceptional cases in which they may be surpassed and the correction period for deviations in any of those cases.

b) The methodology and procedure to calculate the structural deficit.

c) The responsibility of each Public Administration in case of noncompliance of the budgetary stability goals.

6. The Autonomous Communities, under their respective statutes and within the thresholds set forth in this Section, shall adopt the appropriate provisions for the implementation of the principle of stability in their budgetary regulations and decisions". 
from members of Esquerra Republicana-Izquierda Unida-Iniciativa per Catalunya Verts who felt that this procedure infringed their right to equal access to public functions and positions (Section 23.2 of the Spanish Constitution), the agreed procedure was followed. Twenty-four (24) amendments were presented, some of which were rejected, including a proposal for a full amendment and an alternative text presented by the aforementioned parliamentary group, which considered the reform initiative to overlap the provisions established in Section 168 of the Spanish Constitution. The others were rejected after deliberation during the plenary session of Parliament. The proposal was approved with 316 votes in favour. In the Senate, the initiative was submitted to the Constitutional Committee. Twenty-nine (29) amendments were presented; some were not admitted and others rejected by the Committee. The text, which was identical to the version submitted by Parliament, was approved on September 7 with the backing of 233 senators and published in the Official State Gazette (BOE) of September 27.

Once the parliamentary acts were binding, after the Bureau had refused to reconsider them, the members of parliament lodged an appeal for constitutional protection against these acts because their claims had not been upheld and because they considered the fundamental right to which they were entitled under Section 23.2 of the Spanish Constitution had been infringed.

From the outset, the Constitutional Court made it clear it would attach little importance to forms and procedures in this case. Symptomatically, it decided to issue an Order instead of a Judgment, which would have been more appropriate, as indicated by the dissenting vote of Judge Pérez Tremps, on the grounds that the appeal was actually rejected after in-depth examination of the substance of the matter and not dismissed since it was not clear that the law had been infringed and the matter was clearly important from a constitutional standpoint given the novelty of this situation and its impact on an aspect as important as participation in the constitutional review procedure.

However, as mentioned previously, the irrelevance of forms of procedure did not end there; it also affected the constitutional reform itself.

The Spanish Constitution explicitly establishes material limits on the power to reform Section 167 of the Spanish Constitution (De Vega, 1985; Pérez Royo, 1987; Contreras Casado, 1992). This procedure is reserved for partial revisions of the Spanish Constitution that do not affect the Preliminary Title, Chapter II, Division I of Part I, or Part II thereof; in order to revise any of these provisions, it is necessary to follow the most impaired procedure in Section 168 of the Spanish Constitution. In this case, 
although Section 135 appears under Part VII of the Constitution, the plaintiffs considered that its reform also affected the structural principle of the social State mentioned in Section 1 of the Spanish Constitution because they considered that this had been impaired, especially due to the new wording of part three of Section 135; hence, the procedure that should have been followed was the one established in Section 168 of the Spanish Constitution, since a provision in the Preliminary Title was affected. Otherwise, representatives and citizens would be deprived of the opportunity to participate in a procedure that would include the convening of elections after Parliament had deliberated on the appropriateness of the reform and a mandatory and binding referendum after the contents of the reform had been approved by both Houses of Parliament. The Court rejected this argument on the grounds that the Bureau had respected the procedural/material limitations on the reform imposed by the provisions contained in the Constitution, making it impossible during the qualification phase for this body to apply the provisions established in Section 168 of the Spanish Constitution for a purpose other than that expressly stipulated therein, since, as the Order seems to implicitly suggest, the Constitutional Court itself is responsible for extending the application of this provision when ruling on the Bureau's decision. If this has to be controlled, it seems paradoxical not to allow it to determine the most appropriate procedure taking into account the scope of the reform; this would not entail the "risk of leaving the decision on the constitutional reform procedure to the discretion of the governing body of the House", as the Constitutional Court argued. Instead, it would have to comply with the provisions established in the Constitution from the outset, as it was later required to do. The "hyper-rigid" provisions established in Section 168 of the Spanish Constitution actually seek to protect and guarantee specific content; this should not be impaired by the hidden reform of this section through the simplified procedure. If this happened, it would alter the "balance sought by the constituent assembly", something feared by the Constitutional Court.

The emergency and single reading procedures followed to pass the reform were also questioned. While the emergency procedure generally entails reducing periods to half the time normally envisaged or exceptionally shorter periods, as occurred in the case of the period for submitting amendments, single reading procedures exclude discussion of the reform in committee. Sacrificing the debate and the hypothetical achievement of a greater consensus were not convincing arguments despite their democratic relevance for a Constitutional Court that held that the announcement of 
early elections explained an urgency that the Bureau did not have to justify and that, in any case, this did not prevent members of parliament from exercising their amendment right, or even presenting a proposal for a complete revision accompanied by an alternative text. This was rejected on the grounds that the proposed constitutional reform of Section 168 of the Spanish Constitution was actually different to the reform that was being processed, since it was inconsistent with the initiative it intended to modify. In this sense, it resembles consolidated constitutional case law on the matter, which requires a strict correlation between the objects of amendments and initiatives, after the parenthesis resulting from the delivery of Constitutional Court Judgement No. STC 136/2011, which will be discussed below.

The Constitutional Court also failed to consider whether the nature or degree of simplicity of the proposed reform made it advisable to process the initiative by means of the single reading procedure, as stipulated in parliamentary regulations. It seems sufficient for this to be approved by the plenary session of Parliament and for there to be an opportunity to intervene and challenge the decision on the grounds that Section 23.2 of the Spanish Constitution has not been infringed. However, as revealed by the dissenting vote of Judge Gay Montalvo, parliamentary bodies are bound by procedural rules, and the breach thereof may result in the unconstitutionality of the rule approved in breach of the Constitution. Leaving the plenary session of Parliament to decide on which procedure to follow, regardless of the nature or simplicity of the proposal, merely entails implicitly accepting that majority approval of a process with procedural defects that impair plural discussion will eventually resolve its unconstitutionality.

As indicated in the dissenting vote of Judge Gay Montalvo, "the importance of forms in democracy goes beyond what is strictly necessary and facilitates the meeting of different interests and sensibilities characteristic of the plurality of citizens' political opinions and criteria"; the Order suggests that this has not always been taken into consideration.

\section{Legislative proceedings and Finance Bills}

Constitutional Court Judgement STC 136/2011 resolved an appeal on the grounds of unconstitutionality lodged against various provisions of Law 50/1998 of December 30, on fiscal, administrative and social measures, known as the law accompanying the National Budget Law. These types of laws, as indicated in the dissenting vote of Judge Aragón Reyes on the aforementioned judgment, "are an instrument designed to evade the precepts laid down by the Court that halted the 
unconstitutional excess of budget laws containing additional provisions that introduced permanent rules outside the scope of the actual content of the budget law..." and which now "reappear through the window afforded by the accompanying law, passed at the same time as the budget law, within the same period and parallel to same", introducing "unsystematically numerous permanent changes to regulations governing the most disparate of matters". The need to incorporate subsequent political agreements to ensure the proposal is approved or the urgency in approving certain reforms are often used as arguments to justify the use of such laws, when other more appropriate legal instruments exist for responding to the situations described.

Nevertheless, in the opinion of the Constitutional Court, poor legislative technique, in reference to the heterogeneous and multi-sectorial content of accompanying laws, would not affect legal certainty and security, and everything else would result in its political rejection or purely opportunist objections, nor would the existence of procedural defects in its approval necessarily lead to the conclusion that the rule in question violates the Constitution, unless such irregularities resulted in a substantial alteration of the process used by the Houses to reach their decision.

As a result, the confusion between the exercise of legislative and amendment rights is accepted without allowing the majority in the Senate or their supporters to propose and introduce changes whose contents are unrelated to the bill passed in Parliament, thereby preventing minorities from submitting alternative proposals. However, "when the exercise of the right to amend articles does not respect this minimum degree of homogeneity with the amended text, this will affect, contrary to the Constitution, the right of the author of the initiative (Section 87 of the Spanish Constitution)", and may also give rise to a defect of constitutional importance "if this amendment undermines the participation of minorities in the aforementioned [legislative] procedure, which, in turn, could lead to a democratic deficit in the development of a regulation that might eventually contradict the value of political pluralism ... which must necessarily govern the processing of any initiative" and constitute "an illegitimate limitation on the exercise of the rights and powers that are part of the constitutionally relevant functions of political representatives and, consequently, both their right to exercise parliamentary functions (Section 23.2 of the Spanish Constitution) and, intimately related to the foregoing, citizens' right to participate in public affairs (Section 23.1 of the Spanish Constitution)". Surprisingly, however, this constitutional case law on the correlation between drafts and amendments, 
which the judgment itself refers to in the terms indicated, is not applied on the grounds that the appellants failed to identify the "defective" precepts and not the absence of this limitation. The tolerance of such practices impairs democracy by preventing minority participation, amending what is, materially speaking, an initiative that gives "life to a new reality" (Biglino Campos, 1991; Arce Janáriz, 1994; Redondo García, 2001a, 2001b; Pulido Quecedo, 2011: 3; Sánchez Garrido, 2012).

Differentiating between legislative initiative and amendment is key in a pluralist democracy. If legislative initiative, as indicated in a dissenting vote on the judgment, "represents the capacity to initiate the legislative procedure and open the way for the constituent phase of the procedure, understood as the phase in which amendments are presented and discussed", amendment "implies the modification of something that already exists and whose object and nature have been determined previously" and cannot be used to give life to a "new reality, which must also stem from a new initiative".

If the publicity, opposition and debate characteristic of the legislative process had previously always been treated as a guarantee of pluralism inherent in the democratic state, this process now seems to be characterised not so much by respect for minorities but by the application of a majority principle that is applicable beyond the decision-making phase generally considered inherent to the process, until the deliberation phase. As indicated in the Judgement, the majority principle is vital "for the functioning of the democratic system and the supremacy of Parliament, in order to ... guarantee the democratic principle of participation established in the Constitution, which is in turn the demonstration of popular sovereignty ... and which demands the greatest sense of identity possible between governments and the people they govern". However, although this affirmation is not incorrect, it is equally true to say that the minority principle is as important in democratic terms but has been ignored in this case when it should have be taken into consideration. Its presence is crucial in the legislative process. As indicated in the dissenting vote of Judge Aragón, it "expresses the popular will that both houses of the "Cortes Generales" [the two Houses of Parliament: Congress of Deputies and Senate] have the duty to represent (Section 66.1 of the Spanish Constitution). Thus, not only is the law decided by majority but legislative procedure enables the effective participation of minorities through the deliberation of bills submitted by the majority and the presentation of their own proposals through amendments, all in conformity with the unremitting demands of the principle of 
democratic pluralism (Section 1.1 of the Spanish Constitution)". Failure to consider the minority principle, allowing amendments to supersede legislative initiative, undermines the fundamental right to exercise parliamentary office (Section 23.2 of the Spanish Constitution), since it prevents representatives from being able to perform their representative functions in accordance with the terms provided in the Constitution and applicable regulations. Their participation is restricted because senators are limited to approving or rejecting amendments and are prevented from vetoing or presenting and defending alternative amendments to the initiative. Deputies or parliamentarians are limited to ratifying or rejecting "amendments" presented in the Senate instead of being able to discuss and approve initiatives promoted by the Senate in the first instance, as an example of imperfect bicameralism. According to the Judgement, this reveals the difference in identity between democratic principle and majority rule, without taking into consideration minority rule, which, in addition to majority rule, is also part of democratic principle, albeit within different spheres.

\section{Other Parliament's Decisions with the weight of parliamentary legislation}

After months of fruitless negotiations, the approval of Decree-Law 13/2010 of December 3, which, among other measures, modified aircraft uptime, air traffic controllers' breaks and shifts, triggered a wildcat strike that prompted air traffic controllers to abandon their posts en masse on the grounds that they were unable to continue offering services. This forced the closure of Spanish airspace with the consequent interruption of air traffic and inevitable chaos at airports, which affected over 650,000 people (Vidal Prado and Delgado Ramos, 2011). The initial response to this situation consisted in the approval of Royal Decree 1611/2010, of December 3, published on the following day in the BOE (Official State Gazette), which provisionally gave the Ministry of Defence authority over air traffic control functions assigned to AENA (Spanish Airports and Airspace), until the restoration of normal services provided by civil controllers could be guaranteed, and the Chief of Staff of the Air Force was authorised to take any decisions necessary in connection with the organisation and supervision of the air traffic controllers and order absent controllers to occupy their posts. The Government then declared a state of alarm, formalised in Royal Decree 1673/2010, published on December 4, and subsequently informed Parliament, as required in Section 116.2 of the Spanish Constitution.

This decree established that the closure of Spanish airspace as a consequence of 
the situation caused when controllers abandoned their obligations prevented the exercise of the fundamental right to freedom of movement, recognised in Section 19 of the Spanish Constitution, and paralysed an essential public service, namely air transport, resulting in a "public disaster of epic proportions due to the enormous number of citizens affected, the magnitude of the rights infringed and the gravity of the harm caused". In order to restore normal service and re-establish the fundamental right infringed, a state of alarm was declared since other avenues for resolving this "public catastrophe" had proven to be ineffective.

Article 3 of the Decree conferred all air traffic controllers working for AENA the status of military personnel for the duration of the state of alarm in order to apply the penalties established in Article 10 of Organic Law 4/1981 in cases of noncompliance or failure to comply with orders issued by the competent authority, which was none other, as delegated by the Government, than the Chief of Staff of the Air Force and the designated military authorities (as per Article 6 of the Decree), making them subject to criminal law and military disciplinary measures.

Section 116 of the Spanish Constitution and Articles 1.2 and 6 of Organic Law 4/1981 stipulate that states of crisis shall be declared for the duration necessary to ensure normality is restored and for a maximum of duration of 15 days unless extended with express authorisation from Parliament. The Government decided to use this maximum limit and impose a state of alarm for 15 days.

Before the end of that period, the Government availed itself of the provisions established in Section 162.2 of Parliamentary Regulations and asked Parliament for authorisation to extend the state of alarm until January 15 , on the grounds that the situation and problems that had prompted the declaration of a state of alarm persisted, normal service had not been restored in the airport system, no assurances had been given that once the state of crisis was lifted the air traffic controllers would not abandon their posts again - since this would have coincided with the Christmas holidays, it would have had "catastrophic and devastating" consequences for citizens, the economy, especially the tourism sector since more than 100,000 flights were scheduled over that period - and also in order to fulfil international air traffic commitments. Parliament, with 180 votes in favour, gave authorisation for the state of alarm, which ended on December 18, to be extended until January 15. This Resolution was published in the Official State Gazette (BOE) on December 18, together with Royal Decree 1717/2010, establishing the aforementioned extension. 
An appeal was lodged by 322 air traffic controllers against this Agreement adopted by the plenary session of Parliament, authorising the extension of the state of emergency declared in Royal Decree 1673/2010, of December 4, because they considered that it committed the same defects of unconstitutionality and illegality as the latter "due to the lack of factual grounds for declaring the state of alarm", because they considered giving the air traffic controllers military status constituted an "infringement" of some of their fundamental rights, namely the rights to judicial protection, ordinary judge predetermined by law, freedom of expression, assembly, demonstration, association, election to public office, strike and petition - and because authorisation was given without the persistence of the exceptional circumstances that had prompted the declaration of the state of alarm.

This study will not examine, as the appellants intended, whether the situation described equated to the situations established in Organic Law 4/1981 as grounds for the declaration of a state of alarm, whether the measures could be adopted within the same framework or whether the extension of the aforementioned state of alarm was justified in constitutional terms; for information on situations justifying the declaration of a state of alarm and this declaration in general, see Cruz Villalón (1981, 1984), López Garrido (1984), Carro Martínez (1998), Torres Muro (2009). The aim of this study is to examine the reasons why the appeal for constitutional protection was rejected by the Constitutional Court.

The declaration of a state of alarm did not alter the normal functioning of the constitutional State authorities, as established in Section 116 of the Spanish Constitution and Article 1.4 of the Organic Law. The courts continued to perform their functions, which meant that it was possible to control the actions of both those falling within the subjective scope of the declaration and public authorities that exercise their extraordinary powers while the state of alarm is in force.

In relation to the latter, the declaration of the state of alarm can be questioned. The air traffic controllers union understood this to be the case and challenged the Royal Decree containing this declaration before the ordinary contentious-administrative courts. However, the High Court issued an Order on February 10, 2011, stating that it lacked jurisdiction to rule on the validity of the decree. In its opinion, "what is being challenged is an act the contents of which have been approved in their entirety by Parliament from the moment it authorised the extension of the state of alarm in the same terms as those in which it was initially declared"; "thus, the latter was given the 
possibility of exercising all the means of control permitted by law". It therefore considered that this administrative action did not fall under its jurisdiction since it was outside the scope of control defined in Section 106.1 of the Spanish Constitution and Articles 1 and 2 of the Administrative Procedure Act. However, it is important to remember that Article 26 of the Government Act establishes that all actions, without discrimination, are subject to the Constitution and other legislation; the existence of categories exempted from control would contradict the very essence of the rule of law. Even so-called political or government acts contain elements regulated by the Constitution and Law and are consolidated in legal instruments, which are all subject to control. On this occasion, the legal instrument used to declare the state of alarm was a regulation, without the intervention of Parliament, after it initially received simple notification from the authority responsible for taking the decision or extending the duration of the previously established state of alarm, constituting an elevation of the status of either the regulation containing the declaration or the act itself or a change in jurisdiction over the declaration and extension of the state of alarm. The contentiousadministrative court is responsible, in the first instance, for hearing matters concerning regulations ruling on acts that, regardless of their status, are subject to constitutional and legally established limits that must be respected. Refusal to accept control, as in this case, would undermine the right to effective judicial protection, opening the way for an appeal for constitutional protection to be lodged before the Constitutional Court, without prejudice to the fact that this option is also available, even if the case is being heard by the contentious-administrative court, if the breach of fundamental rights were attributable to the declaration itself and the harm caused to the affected parties is not repaired by the ordinary courts ${ }^{3}$.

The appellants did not use this channel. Perhaps conditioned by the Supreme Court's response, the object of the appeal for constitutional protection was none other than Parliament's decision to authorise the extension of the state of alarm, which prompted its rejection by the Constitutional Court on the grounds that it was not a decision or act without force of law, as provided in Article 42 of the Law of the Constitutional Court in order for an appeal for constitutional protection to be lodged

\footnotetext{
${ }^{3}$ The application of the Decree declaring the state of alarm and the measures provided for therein are also subject to control, since Article 3 of the Organic Law provides that "the acts and provisions of the public administration adopted during the proclamation of states of alarm, exception and seige shall not be subject to judicial review in conformity with the provisions established in legislation".
} 
against this decision. In this case, the Court stated in Order 7/2012 that "the parliamentary nature of the Agreement under appeal is clear, and was adopted by the plenary session of Parliament by virtue of a function assigned to the House in the Constitution (Section 116.2 of the Spanish Constitution) and not subject to judicial review by the ordinary courts, since it is not an act concerning employees, administration or asset management". The Constitutional Court is responsible for its control but not through an appeal for constitutional protection. In its opinion, the Agreement had force of law, which meant that it could only be challenged through an appeal alleging unconstitutionality or the matter of unconstitutionality arising following opposition of the corresponding implementing acts before the ordinary courts and the determination by the latter of possible infringements of the Constitution by the agreement regulating those acts.

In the Order, force of law was not defined according to the position of a rule of law in the legal order taking into consideration its form or the concepts of active and passive force of law, but rather the capacity of a rule, decision or act "to affect legal or equivalent rules, in other words derogate, suspend or legitimately modify them", as occurs, in the Constitutional Court's opinion, in the case of declarations of states of alarm provided under Section 116 of the Spanish Constitution and parliamentary authorisations of the extension of these states of alarm. These were not "merely authorisations because they had legislative or regulatory content ... insofar as they subscribed the scope, terms and conditions of the state of alarm or emergency established or requested by the Government". It was precisely this impact "on the system governing the applicability of certain legal rules, including rules or regulations given force of law, which ... can, with restrictive conditions, be moved or suspended during the period in which a state of emergency is in force", that gives them force of law.

If the determining factor for giving force of law is compliance with the abovementioned function, this force should, a fortiori, be given to the Decree declaring the state of alarm. However, the Constitution does not do this. Parliamentary authorisation to extend the state of alarm did not affect the declaration from a material, territorial, or personal perspective. The Government had already, pursuant to the powers conferred upon it by a regulation, consolidated these elements and subsequently suspended the ordinary system. The dissenting vote of Judge Álvarez Ortega, supported by judges Delgado Bario and Pérez Tremps, indicated that "if a substantive rule of law 
establishing the rights and freedoms of citizens is not qualified by the Constitution as a rule with force of law, much less can be said to apply to an act extending the rules in question, even if this act is an act of Parliament"; hence, its control cannot be channelled through an appeal for constitutional protection or the matter of constitutionality.

The Constitutional Court, when addressing the issue of force of law in order to justify the impermissibility of control through the appeal for constitutional protection, used the concept of hierarchy, which is based on the different forms of rules according to the body responsible for issuing them and the procedure adopted for their approval. This form will determine its position in the legal order, regardless of its content and function. Instead of taking this into account, the Constitutional Court employed a functional criterion to reconstruct the category of force of law that is not related in any way with the foregoing since it made the legal force of the Agreement and its harmonisation with formal law dependent not on the existence of active force of law and the absence of passive force of law between both elements but on the capacity to challenge, suspend or modify the applicability of the law, ignoring the fact that hierarchy is a criterion used to explain the relationships between regulations according to their validity (De Otto, 1987). Again, in a completely different sphere, form and procedure were of secondary importance and the control of the Constitutional Court was sacrificed through the appeal for constitutional protection and, with it, citizens' legitimate right to activate judicial mechanisms to protect their rights against provisions, decisions or acts adopted by public authorities that undermine such rights.

\section{Democracy, rule of law and protection of Parliament's minorities}

The previous sections have drawn attention to what the authors consider to be the deterioration of the democratic principle in both spheres due to a devaluation of procedures.

In the democratic State, equality and freedom must go hand in hand.

Equality must not only be guaranteed when implementing rules. It also requires all parties to identify with their contents through participation in the formulation of the collective will of those who will be bound by those regulations with the same political force; this objective can be achieved by guaranteeing universal suffrage and through application of the "one man one vote" criterion. Majority rule, rather than a solution given the unlikelihood of unanimity on this issue, is imperative in order to achieve this equality given its neutrality with respect to the different options available, since it 
identifies collective decisions with those of the majority, combining wishes that express different preferences with respect to the final outcome without prioritising any.

Ensuring decisions are adopted by the majority - regardless of who the majority are - is insufficient in a democratic state because this principle, together with equality, is also accompanied by the principle of freedom, understood as individual participation in state affairs. The combination of both principles requires a minority principle that ensures the minority are involved in the decision-making process, not adopting decisions but participating in the deliberations that lead to the taking of those decisions. Restricting the self-determination of the minority, who are subject to the wishes of the majority in this decision-making process, does not undermine the democratic principle because it does not identify collective will with that of all citizens; to combine the principles of freedom and equality, it is sufficient for everyone to be able to participate in the decision-making process and express their different opinions. The position of minorities is not guaranteed by allowing them to express their dissent when decisions are being taken or by emphasizing the provisional nature of a decision that may change when they cease to be a minority. If the majority principle must be present in decisionmaking processes, the minority principle must be upheld in prior deliberations that can only make the decision legitimate if they are plural, i.e. the result of a dialogue between all parties considered equal and respecting their right to political self-determination. The necessary compatibility between the creation by the majority of a single will and the equal validity of the individual will of individual citizens can be achieved through a procedure in which the majority and minorities make their contributions to the final outcome, making this their own.

In short, the equality and freedom characteristic of a democratic State make it an inclusive state, either by allowing, through universal suffrage, a significantly large number of citizens to participate in the decision-making process, or involving all participants, regardless their ideas and number, in the entire process from the presentation of the initiative to the voting stage, or, finally, introducing majority rule which, from a position of neutrality, leave decision-making in the hands of the majority, regardless of who they are.

The two cases described fall within this second part of the process.

In the reform of the Constitution, the mere existence of a procedure that opens the door for its complete revision, without including intangibility clauses, may seem to be a sufficient guarantee for minorities. However, this maximum degree of acceptance 
of contents that contradict those envisaged in the Constitution is frustrated to some extent by the obligation to comply strictly with procedural requirements that would seriously hinder the success of such a reform initiative; from the presentation of an initiative left in the hands of the parliamentary majority or majority minorities, excluding citizens, to the voting stage in which strengthened majorities prefer the conservative option of the original text to the detriment of the proposed amendment, even if this involves all parties since a broad consensus is needed to approve the reform. However, the deliberation stage is the key moment of minority participation; this deliberation, as provided in Section 167 of the Spanish Constitution, is not very different to deliberation in ordinary legislative procedures, guaranteeing the presence of all groups and plural discussion in which arguments for and against the reform must be heard, with the option of incorporating alternatives in the aforementioned reform. Undermining the discussion by reducing processing times, reducing the scope in which such discussions can take place, precipitating or preventing the presentation of amendments, are not the best way to safeguard the democratic principle; a more serious transgression of that principle would be toleration of a reform which, taking into account its contents, requires the procedure established in Section 168 of the Spanish Constitution in order to prosper, transitioned through the simplest provisions contained in Section 167 of the Spanish Constitution, without ensuring additional guarantees for minorities such as the calling of elections, the requirement for a $2 / 3$ majority or mandatory referendum. All these aspects are addressed in Constitutional Court Order ATC 9/2012 and are not resolved in the most satisfactory manner.

As shown previously, in ordinary legislative procedure pluralism also requires the articulation of mechanisms that allow minorities to participate in the formation of collective will. In addition to the principle of equality, which must guide the decisionmaking process, the proposal and deliberation phase must comply with the principle of freedom and with it the protection of minorities. If Parliament wishes to be a decisionmaking body, it must first be a deliberative body, serving as a channel for the expression of different groups, including minorities. The pluralistic approach underpinning the power to promote legislative initiative seems to favour the integration of minorities; these also have the right to amend or draft bills submitted by others. Finally, they must be involved in deliberations in order to legitimise majority rule through their involvement in a procedure in which they can influence adopted resolutions without participating in the decision-making process. The confusion 
between amendments and initiative, evident in the case of the accompanying law the subject of Constitutional Court Judgement STC 136/2011, unjustifiably restricts the role that minorities are expected to play in the legislative process and with it their right to participate in public affairs, exercising their position as provided in legislation currently in force. The acceptance of amendments presented by the majority or their supporters that are inconsistent with the proposal and their classification as amendments and not according to their real nature, i.e. as initiatives, prevents minorities from exercising their real right to present amendments. Majority support of a process that undermines plural discussion cannot restore the democratic deficit incurred by this procedure or correct any defects of unconstitutionality.

The reconstruction of the concept of force of law in Constitutional Court Order ATC 7/2012, which ignores the form and subsequent position of the provision, resolution or act in the legal order, linking it to the consequences it has on the applicability rather than the validity of regulations, significantly curtails the judicial protection of the smallest minority - the individual - and his or her access to the Constitutional Court in order to defend his or her rights. Giving force of law to the Agreement authorising the extension of the state of alarm restores control over this matter to constitutional review procedures, thus preventing the affected parties from exercising their right to appeal for constitutional protection, at the same time as they were unable to challenge the Decree declaring the state of alarm due to the declared lack of jurisdiction of the High Court. The victims are powerless to react against this apparent infringement of their fundamental rights resulting from the declaration of the state of alarm, since the High Court seems to have left control of this matter in the hands of Parliament following the authorisation to extend the state of alarm, and the Constitutional Court, by giving force of law to the Agreement imposing this extension, rules out the possibility of this being challenged by means of an appeal for constitutional protection. In this case, the failure to take into consideration forms has resulted in jurisdictional privileges being enjoyed by those who do no deserve such privileges and the unjustified sacrifice of judicial protection for those whose rights may have been breached. The Constitutional Court monopolises the authority to exclude laws from the legal order at the behest of bodies or parts of constitutional bodies; the position of the law in the Spanish legal system and the democratic advantages afforded by the body presenting the initiative and the procedure followed in the development of the law explain this deference, which would be impossible to justify if extended to other 
rules or acts that do not comply with these formal-procedural characteristics.

As described by Biglino Campos (1991, p. 63), the procedure is not an end in itself but also in many instances projects the requirements of the democratic principle in the creation of legislation. In short, in a democratic state respect for procedures in the creation of law, especially in relation to the matters discussed here (legislative initiative, right of amendment, legislative processing, the characteristics of deliberations), is vital in order to ensure the participation of minorities ${ }^{4}$, but minorities can also be protected by arbitrating judicial mechanisms that can respond, at their behest, to infringements of their rights and by not unduly preventing their access to such mechanisms; the paradox is that the instrument designed to act as a guarantee, namely procedure coupled to a form, becomes a ground for exclusion.

\section{BIBLIOGRAPHY}

ARCE JANÁRIZ, A. (1994) El derecho de enmienda por el Tribunal Constitucional. Revista española de Derecho Constitucional, 41, pp. 151-172.

CARRO MARTÍNEZ, A. (1998) Art. 116. Situaciones de anormalidad constitucional. In: ALZAGA VILLAMIL, O. Comentarios a la Constitución española de 1978. 1th ed. Madrid: Cortes Generales-Edersa, pp. 210-262.

BIGLINO CAMPOS, P. (1991) Los vicios en el procedimiento legislativo. 1th ed. Madrid: Centro de Estudios constitucionales.

CONTRERAS CASADO, M. (1992) Sobre el Título X de la Constitución española: de la reforma constitucional. Revista de Derecho Político, 37, pp. 303-318.

CRUZ VILLALÓN, P. (1981) El nuevo derecho de excepción (Ley orgánica 4/1981, de 1 de junio). Revista española de Derecho Constitucional, 2, pp. 93-128.

CRUZ VILLALÓN, P. (1984) Estados excepcionales y suspensión de garantías. 1th ed. Madrid: Tecnos.

DE OTTO, I. (1987) Derecho Constitucional. Sistema de fuentes. 1th ed. Barcelona: Ariel.

DE VEGA, P. (1985) La reforma constitucional y la problemática del poder constituyente. 1th ed. Madrid: Tecnos.

\footnotetext{
${ }^{4}$ As described by BIGLINO CAMPOS, 1991: 63, the procedure is not an end in itself but also in many instances projects the requirements of the democratic principle in the creation of legislation.
} 
LÓPEZ GARRIDO, D. (1984) Estados de alarma, excepción y sitio. Trabajos parlamentarios. 1th ed. Madrid: Cortes Generales.

PÉREZ ROYO, J. (1987) La reforma de la Constitución. 1th ed. Madrid: Congreso de los Diputados.

PULIDO QUECEDO, M. (2011) La reformulación jurisprudencial del derecho de enmienda. Actualidad jurídica Aranzadi, 827, pp. 3.

REDONDO GARCÍA, A. Ma. (2001) El derecho de enmienda en los procedimientos legislativos de las Cortes Generales. 1th ed. Madrid: Congreso de los Diputados.

REDONDO GARCÍA, A. Mª (2001) El derecho de enmienda como instrumento de integración del pluralismo político en la fase central de los procedimientos legislativos de las Cortes Generales. Revista de Derecho Político, 50, pp. 189-220.

SÁNCHEZ GARRIDO, J. A. (2012) Procedimiento legislativo: exigencia general de conexión u homogeneidad entre las enmiendas y los textos a enmendar. La Ley, 7775, pp.1-6.

TORRES MURO, I. (2009) Art. 116. Los estados excepcionales. In CASAS BAAMONDE, Ma $M^{\mathrm{a}}$ E. y RODRÍGUEZ-PIÑERO Y BRAVO-FERRER, M. (eds.) Comentarios a la Constitución española. XXX aniversario. 1th ed. Madrid: Fundación Wolters Kluwer, pp. 1814-1820.

VIDAL PRADO, C. and DELGADO RAMOS, D. (2011) Algunas consideraciones sobre la declaración del Estado de alarma y su prórroga. Revista española de Derecho Constitucional, 92, pp. 243-265. 